\begin{tabular}{ccc}
\hline Tanggal diterima & Tanggal direvisi & Tanggal Terbit \\
\hline 3 Februari 2019 & 27 Februari 2019 & 25 Maret 2019 \\
\hline
\end{tabular}

\title{
Manhaj Tarjih Dan Tajdid : Asas Pengembangan Pemikiran dalam Muhammadiyah
}

\author{
Bahar Agus Setiawan \\ Dosen Program Studi Pendidikan Agama Islam Fakultas Agama Islam \\ Universitas Muhammadiyah Jember \\ E-mail : baharsetiawan@unmuhjember.ac.id
}

\begin{abstract}
This literature review aims at exploring both manhaj tarjih and tajdid in Mubammadiyah tradition as a basis for developing reasonings. Islamic study within Mubammadiyah tradition is not only intended for use in studying religious beliefs, but also as a process for understanding Islam more comprehensively, so that it can optimize the value of Islam as 'rahmatan lil alamin' not only at the conceptual level but also, more importantly, at the practical level in line with the philosophy of baldatun toyyibatun wa rabbun ghofur. The basis for developing thoughts in Muhammadiyah is predicated upon 16 main points, the rules of tarjih based on ijma', qiyas, maslahah mursalah and al-urf, while the tarjih method covers bayani, burhani and istislahi such as pertaining to reasoning for using bayani, burbani and irfani.
\end{abstract}

Keywords: Manhaj Tarjih and Tajdid, Thoughts Development, Mubammadiyah

Abstrak

Artikel ini yang merupakan kajian berbasis literatur bertujuan untuk mengeksplorasi manhaj tarjih dan tajdid dalam tradisi Muhammadiyah sebagai asas dalam mengembangan pemikrian. Kajian keislaman dalam Muhammadiyah tidak hanya diperuntukan dalam kerangka studi agama an sich, tetapi sebagai proses untuk memahami Islam secara komprehensif sehingga dapat menghadirkan Islam rahmatan lil alamin bukan hanya pada tataran konsep tetapi lebih aplikatif sejalan dengan filosofi baldatun toyyibatun wa rabbun ghofur. Asas pengembangan pemikiran Muhammadiyah didasari atas 16 pokok uraian, kaidah tarjih merujuk pada ijma', qiyas, maslahah mursalah dan al-urf, sedangkan metode tarjih meliputi bayani, burhani dan istislahi adapun berkaitan dengan pemikiran menggunakan bayani, burhani dan irfani.

Kata Kunci : Manhaj Tarjih dan Tajdid, Pengembangan Pemikiran, Muhammadiyah

\section{PENDAHULUAN}

Kelahiran Muhammadiyah tidak bisa dilepaskan dari gerakan pembaharuan Islam. Sosok KH. Ahmad Dahlan sebagai pencetus sekaligus sebagai inovator pola gerakan merupakan figur central yang tidak bisa dilepaskan dalam memberikan warna dan ciri khas dalam gerakan Muhammadiyah. Pola gerakan Muhammadiyah yang vis a vis kultur masyarakat jawa pada saat itu, dianggap sebagai gerakan yang bertentangan dengan tradisi masyarakat. Gaya dakwah dan gerakan KH. Ahmad Dahlan yang banyak dipengaruhi oleh tokoh-tokoh gerakan pembaharuan seperti Jamaludin Al-Afghani, Rasyid Ridha, Muhammad Abduh dan tentu saja figur central gerakan wahabiah yaitu Muhammad Ibn Abdul Wahab. Pengaruh tokoh-tokoh tersebut tercermin dan dapat dilihat dari pola gerakan dan 
gaya dakwah KH. Ahmad Dahlan yang cenderung modert yang merujuk pada model Muhammad Abduh (Schacht, 1991) dan Rasyid Ridha, tetapi tanpa kompromi yang merujuk pada model Muhammad Ibn Abdul Wahab (Kim, 2010). Dalam konteks Muhammad Ibn Abdul Wahab, tidak bisa dilepaskan atas perannya ketik Arab Saudi memulai kebangkitan (Arab Renaissance) (Haj, 2002; Dennerlein \& Hamid, 2010).

Pengaruh gerakan pembaharuan Islam terhadap KH. Ahmad Dahlan sebagai figur central pada gerakan Muhammadiyah, melahirkan perspektif Muhammadiyah sebagai gerakan reformis modernis. Sehingga tiga ciri gerakan yang menjadi identitas Muhammadiyah yang terangkum dalam triloginya yaitu sebagai gerakan Islam, dakwah dan tajdid. Realitas ini merujuk pada sosioagama di Indoensia, dimana tradisi tahayul, bid'ah dan khurafat yang begitu kuat dalam terminologi Geertz disebut dengan istilah Islam Jawa (Tago, 2013). Disisi lain realitas sosio-pendidikan menunjukkan adanya dikotomi sistem pendidikan Islam dan sistem pendidikan umum, sehingga melahirkan ketimpangan pada lulusan sekolah umum di satu pihak dan lulusan pesantren di lain pihak (Nashir, 5 : 2016).

Wajah Muhammadiyah sebagai gerakan modernis dan reformis dalam Islam memiliki karateristik yang unik, kesan doktriner namun sistematis teologis, eksklusif namun inklusif, anti jawa namun banyak hal dalam Muhammadiyah merupakan perwujudan sifat baik orang jawa (Nakamura, 2012). Merujuk pada perspektif tersebut, maka Muhammadiyah dalam terminologi sebagai sebuah institusi dan disisi lain sebagai sebuah idiologi mengahadirkan pola gerakan yang bersifat komprehensif. Tidak hanya pada aspek sosio-agama tetapi juga pada aspek yang lain sehingga bagi Muhammadiyah menjadi keniscayaan menghadirkan pandangan-pandangan baru baik dalam konteks keagamaan maupun dalam konteks sosial masyarakat.

Keinginan dalam menghadirkan perspektif dan pemahaman keagamaan yang selaras dengan alQur'an dan Sunnah sebagai semboyan gerakan Muhammadiyah, peran Majlis Tarjih dan Tajdid sebagai lembaga dalam Muhammadiyah memiliki posisi yang central dan fundamental. Dalam melakukan pembaharuan tentu Muhammadiyah berpegang pada manhaj yang diyakininya. Manhaj tarjih dan tajdid merupakan proses Muhammadiyah yang berbasis metode dalam menghadirkan perspektif baru sesuai dengan al-Qur'an dan Sunnah tentang seluruh aspek kehidupan bermasyarakat. Tidak hanya berkaitan dengan agama dan keagamaan tetapi behubungan dengan aspek pendidikan, politik, sosial, ekonomi dan lain sebagainya. Sehingga istibat hukum yang dilahirkan dalam Muhammadiyah selalu bersifat indepnden sebagai hasil tarjih dan tajdid dalam Muhammadiyah. Manbaj tarjih dan tajdid dalam Muhammadiyah dihasilkan dalam rangka mengaktualiasasikan Islam secara kaffah sebagai bagian dari keinginan menghadrikan islam rahmatal lil alamin sehingga citacita Muhammadiyah baldatun toiyibatun wa rabbun ghofur dapat diwujudkan.

\section{PEMBAHASAN}

Pengertian Manhaj Tarjih dan Tajdid dalam Muhammadiyah

Pengertian dan definisi manhaj selalu diidentikan dengan proses dalam mengemukakan 
perspektif atau sudut pandang baik yang bersifat individu (Fatwa et al., 2013)(Karim, 2015) maupun kelompok/gerakan seperti manhaj salafi (Duderija, 2010) dan lainnya. Istrilah manbaj secara etimologi menurut Ibn Mansur dalam bukunya yang berjudul "Lisan al-Arab" seperti yang dijelaskan Hajji Syed Hussin, berasal dari kata "nahaja/نه -yunabiju/ "ينهج" yang mempunyai makna طريق (cara/methode) (Haji Syed Hussin, 1996). Pendeknya istilah manhaj dapat disimpulakan dengan arti metode/jalan untuk menentukan sebuah perspektif, sudut pandang, pemahaman, hukum dan lainnya.

Kata " rojjaba - yurajjibu- tarjïban “ merupakan asal kata tarjih, bermakan mengambil sesuatu yang lebih kuat. Menurut istilah, tarjih dalam perspektif persyarikatan, yaitu membandingbanding pendapat dalam musyawarah dan kemudian mengambil mana yang mempunyai alasan yang lebih kuat.

Istilah tarjih mempunyai makna pengambilan kesimpulan terhadap dalil syar'i yang lebih kuat diantara dalil-dalil yang ada yang secara dzahir terlihat bertentangan. Tarjih juga dimaknai sebagai evaluasi terhadap berbagai pendapat fikih yang sudah ada mengenai suatu masalah untuk menentukan mana yang lebih dekat kepada esensi al-Quran dan as-Sunnah dan lebih maslahat untuk diterima. Tarjih merupakan salah satu tingkatan ijtihad dan berada pada level ijtihad yang rendah, berdasarkan tingkat ijtihad yang mencangkup 4 macam yaitu : a. ijtihad mutlak dalam usul dan cabang; b. ijtihad dalam cabang; c. ijtihad dalam mazhab; dan d. ijtihad tarjih.

Perkembangan makna tarjib telah mengalami reduksi makna dari makna asli dalam disiplin ilmu usul figh, yakni tarjih tidak hanya diartikan kegiatan sekedar kuat-menguatkan suatu pendapat yang sudah ada, melainkan jauh lebih luas sehingga identik atau paling tidak hampir identik dengan kata ijtihad itu sendiri. Tarjih dalam perspektif Muhammadiyah dimaknai sebagai "setiap aktifitas intelektual untuk merespons realitas sosial dan kemanusiaan dari sudut pandang agama Islam, khususnya dari sudut pandang norma-norma syariah."

Adapun makan tajdid Secara etimologi, tajdid berasal dari Bahasa Arab "jaddada" yang artinya memperbaharuhi, dan "tajaddada al-syai", artinya sesuatu itu menjadi baru. Sebagai contoh adalah kata-kata "jaddada al-wndû", artinya memperbaharuhi wudhu, dan "jaddada al-abda", artinya memperbaharuhi janji. Dari sini, makna tajdid memberikan gambaran pada pikiran kita terkumpulnya tiga arti yang saling berkaitan dan tidak terpisah : 1) bahwa sesuatu yang diperbaharuhi itu telah ada permulaannya dan dikenal oleh orang banyak, 2) bahwa sesuatu itu telah berlalu beberapa waktu, kemudian usang dan rusak, dan 3) sesuatu itu telah dikembalikan kepada keadaan semula sebelum usang dan rusak (Zarkasyi, 2013). Adapun landasan syar'i tentang tajdid yang banyak dijadikan rujukan mengacu pada 3 hadist yaitu :

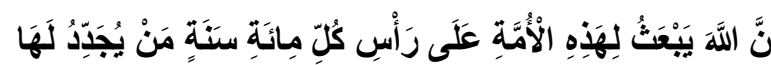

Artinya :

"Seseungguhnya Allah SWT mengutus untukumat ini setiap awal seratus tahun orang yang memperbarui agamanya" (HR. Abu Daud)"

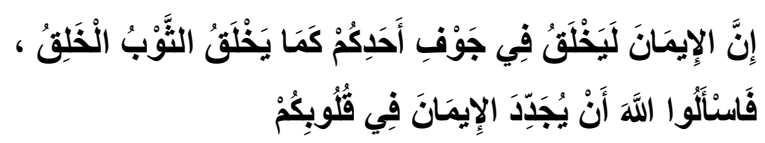

Artinya :

"Sungguh, iman itu dapat usang sebagaimana 
pakaian dapat menjadi usang. Karenanya mohonlah selalu kepada Allah agar memperbaharui iman yang ada dalam jiwamu." (HR. Ath-Thabrani dan AlHakim.)"

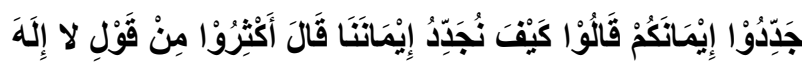
إلِّاً الله

\section{Artinya :}

"Perbaharuilah iman kalian semua!' Para sahabat bertanya, 'Bagaimana caranya, Ya Rosulallah?' Kemudian Rasulullah menjawab, 'Perbanyaklah membaca Lâ ilâh illâ Allâh.“ (HR. Ibnu Hanbal)”.

Pemaknaan tajdid juga mengacu pada dua konteks yaitu reformasi dan modernisasi (Jamil, 1995). Hal ini tidak bisa lepas bahwa tajdid dapat dilihat dalam aspek teologis dan historis. Dalam aspek teologis, dalam proses tajdid, landasan atau dasar-dasar keagamaan yang menjadi rujukan dalam pelaksanaanya. Maka tujuan dalam dalam aspek teologis ini, tajdid merupakan proses untuk proses purifikasi (permurnian) (Bandarsyah, 2016). Sedangkan dalam aspek historis, tajdid merupakan fakta sejarah peradaban Islam yang terjadi sebagai upaya menggagas kembali upaya Islamic Revivalism.

Lalu apa yang dimaksud dengan manhaj tarjih dan tajdid dalam Muhammadiyah? Untuk memberikan definisi yang baik dan mungkin tepat harus tidak bisa disimpulkan secara sederhana dari pengertian yang telah dideskripsikan. Dalam memberikan definisi/pengertian manbaj tarjib dan tajdid Muhamadiyah harus merujuk pada konteks institusi yang menaungi hal ini yaitu Majlis Tarjih dan Pengembangan Pemikiran Islam (MTPPI). Ada 6 tugas pokok yang dimiliki oleh MTPPI. Berdasarkan deskripsi 6 tugas MTPPI, disimpulkan bahwa manhaj tarjih dan tajdid Muhammadiyah adalah metode atau cara Muhammadiyah dalam melaksanakan tarjih (ijtihad) dan tajdid (pemurnian dan modernisasi) baik dalam bidang keagamaan maupun bidang sosial, politik, pendidikan, kemasyarakat dan lainnya.

\section{Asas-Asas Ijtihad dalam Muhammadiyah}

Secara historis, kemunculan larangan pada ahli fikih (fuqoha) tentang pelaksanaan ijtihad terjadi sekitar abad 3 hijriah. Dampak nyata statemen ini menjadi penyebab kemunculan paradigma baru dalam dunia Islam yang dikenal dengan era "Penutupan Pintu Ijtihad (insidad fii albab al-ijtihad" atau "gerbang ijtihad tertutup (Hallaq, 1984; Hasan, 2003). Dalam kondisi inilah fenomena "taqlid" merajalela sehingga memposisikan Islam sebagai peradaban yang terus merosot. Muhamamdiyah sebagai gerakan keagamaan di satu sisi dan gerakan sosial kemasyarakatan disisi lain, melihat ijtihad merupakan dinamika yang haru selalu dilakukan sehingga mampu menjawab tantangan dan problematika umat Islam. Gambaran kongkrit dalam perspektif ini, adanya Majlis Tarjih dan Tajdid merupakan bukti kongkrit akan hal tersebut. Menurut Abdurrahman (2002), dalam Muhammadiyah, asas-asas ijtihad seperti yang dijelaskan dalam Pokok-Pokok Manhaj Tarjih Muhammadiyah memiliki 16 pokok pikiran yang terdeskripsi secara jelas.

\section{Kaidah dan Metode Tarjih dalam}

\section{Muhammadiyah}

\section{1). Kaidah Tarjih dalam Muhammadiyah}

Penggunaan kaidah hukum dalam pelaksanaan ijtihad/tarjih, tidak lepas untuk merujuk pada konsep “maqasidi syari'ab”, sebagai makna dan tujuan yang dikehendaki dalam mensyariatkan suatu hukum bagi kemaslahatan 
umat manusia (Kamali \& Origins, 2008; Auda, 2008; Jamil, 1995). Dalam terminologi Muhammadiyah konsep sejalan dengan salah satu kaidah yang digunakan yaitu "maslahah mursalab". Meskipun secara terminologi kedua istilah ini memiliki pengertian yang berbeda namun memiliki kesamaan terakit dengan asas kemaslahatan.

Kaidah atau yang lebih dikenal dengan istilah teknik, dalam Muhamamdiyah untuk melakukan ijtihad menggunakan 4 kaidah disamping kaidah-kaidah yang sudah berlaku secara umum dalam Islam. 4 kaidah tersebut adalah : a). Ijma'; b). Qiyas; c). Maslabah Mursalab; dan d). Urf.

\section{a) Ijma}

Pengertian ijma' ulama' menurut Syaifuddin (2012 : 48) adalah:

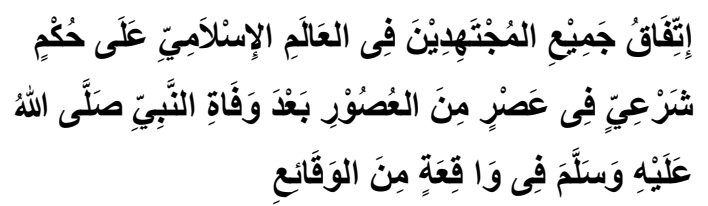

Artinya:

"Kesepakatan semua mujtahid di dunia Islam tentang hukum syara' pada suatu masa setelah wafatnya Nabi saw. terhadap suatu kejadian".

Pemahaman terhadap deskripsi diatas menjelaskan bahwa ijma' mengandung beberapa unsur antara laian :1. Adanya kesepakatan seluruh mujtahid dari kalangan umat Islam; 2. Kesepakatan yang dilakukan harus dinyatakan secara jelas; 3. Kesepakatan terjadi setelah wafatnya Rasulullah saw; dan 4. Yang disepakati adalah hukum syara (Dahlan, 2011 : 146-147).

\section{b). Qiyas}

Qiyas memiliki 4 rukun(Syarifuddin, 2012: 52-53). (Qiyas menurut istilah ahli ushul dalam (Syarifuddin, $2012:$ 52) adalah:

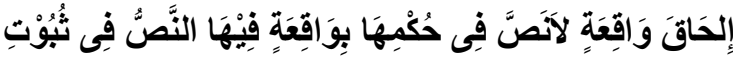

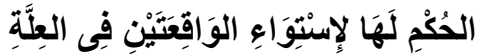

Artinya:

"Menghubungkan suatu kejadian yang tidak ada nash hukumnya denga kejadian lain yang telah ada nash hukumnya, untuk menetapkan hukum padanya karena samanya kedua kejadian itu dalam ilatnya".

c) Maslahah Mursalah

Maslahah mursalah atau (maslahat muthlaqah) menurut Syarifudin (2012:64) adalah:

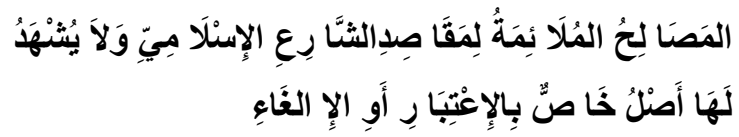

Artinya:

"Kemaslahatan yang searah dengan tujuan syari' al-Islami (Allah swt.), namun tidak petunjuk khusus yang mengakuinya atau menolaknya".

Adapun kontruksi kemaslahatan terbagi atas dua macam kaidah yaitu maslahah gharibah dan maslahah mursalah (Haroen, 1997 : 119).

d) Urf

'Urf atau disebut juga adat menurut definisi ahli ushul fiqh dalam Syarifuddin (2012 : 71) adalah:

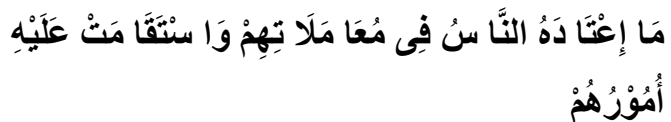

Artinya:

"Sesuatu yang sudah dibiasakan oleh manusia dalam pergaulannya dan telab mantap dalam urusanurusannya".

Adapun konsep 'Urf terbagi atas dua macam yaiu 'urf Qauli dan 'urf fill (Syarifuddin, 1997: 367-368).

\section{2). Metode Tarjih dalam Muhammadiyah}

Berkaitan dengan pelaksanaan tarjih, ada 3 metode tarjih/ijtihad dalam Muhammadiyah yang meliputi :

a) Ijtihad Bayani.

Ijtibad bayani sebagai salah satu unsur yang 
digunakan dalam pelaksanaan tarjih/ijtihad dalam Muhammadiyah berkaitan erat dengan konteks nash yang bersifat mujmal, baik dikarenakan esensi maksud makna yang belum jelas maupun dikarenakan kalimat (lafadz) yang memiliki makna bercabang/ganda (musytarak) atau disebabkan definisi lafal/kata yang memiliki arti jumbub (mutasyabih).

\section{b) Ijtibad Qiyasi}

Ijtihad qiyasi merupakan proses analogi suatu hukum yang terdapat dalam al-Qur'an mauapun sunnah terhadap perkembangan problemtika hukum yang dihadapi oleh umat Islam. Beberapa contoh praktek ijtihad qiyasi yaitu menganalogikan hukum zakat komoditas sengon dengan zakat pertanian, menganalogikan hukum sabu-sabu ataupun narkotika dengan hukum dasar haramnya khamr.

\section{c) Ijtihad Istislahi}

Konsep Ijtihad istiblabi sebagai sebuah dasar untuk memutuskan suatu hukum yang belum terdapat nash-nya yang jelas dan khusus. Ijtihad istilahi merujuk pada illat untuk kemaslahatan, seperti membolehkan pengelolaan tanah wakaf dengan pertimbangan dapat menghasilkan dan memelihara tanah tersebut dan lainnya. Pendeknya pada konteks ijtihad ini, hukum dasar yang digunakan adalah alasan yang menuju kebaikan sesuai dengan aturan al-qur'an dan sunnah.

Metode Pengembangan Pemikiran dalam Muhammadiyah : Sebuah Refleksi Analisis

Pengembangan pemikiran menjadi keniscayaan bagi eksistensi sebuah organisasi tidak terkecuali bagi Muhammadiyah. Disisi lain, pengembangan pemikiran sebagai bentuk dinamisasi sebuah pergerakan. Muhammadiyah sebagai organisasi modern harus mampu menunjukkan pengembangan pemikiran yang terus tumbuh dan berkembang sebagai tradisi dan kulturnya. Muhammadiyah dalam pengembangan pemikiran merujuk pada 3 metode yaitu bayani, burhani dan irfani (Abbas, 2016). Perkembangan pemikiran dalam Muhammadiyah tidak lepas dari konteks maslahah sebagai preferensi dalam perspektif Islam (Jalil, 2006). Pememahaman terhadap maslahah itu sendiri terdapat 2 sudut pandang yang berbeda, satu pada posisi maslahah sebagai otoritas nash, disisi lain akal dapat berperan aktif (Makiah, 2014).

Metode bayani secara etimologi sebagai kesinambungan (al-waslu): keterpilahan (al-fashlu): jelas dan terang (al-zhuhur wa al-wudlhuh): dan kemampuan membuat terang dan generic (makiah, 2014). Epistimologi bayani secara etimologi berasal dari kata bayan merupakan pendekatan yang merujuk pada teks, sehingga pengembangan pemikiran dalam Muhammadiyah sebagai landasan dasarnya harus merujuk pada Al-qur'an dan sunnah. Adapun burhani dapat dimaknai sebagai al-buijah yang jelas (al-bayyinah/clear) serta dapat membedakan (distinc/al-fashl); demonstration (Inggris), yang mempunyai akar bahasa Latin: demonstratio yang bermakna memberi isyarat, sifat, keterangan, dan penjelasan (Abbas, 2016). Berdasarkan deskripsi tersebut, penulis, memaknai burhani sebagai proses penjelasan yang dapat membedakan dan memberikan penejlasa terhadap teks yang dikaji dengan penggunaan nalar/akal. Sedangkan pendekatan irfani yang mempunyai 
makna yang semakna dengan kata ma'rifah, berkaitan dengan pengalaman atau pengetahuan langsung dengan objek pengetahuan. Irfani lebih dipahami sebagi pendekatan otentik yang bertumpu pada pengalaman intuisi sebagai pengetahuan yang bersifat iluminasi (pencerahan)(Abbas, 2016).

Pendekatan bayani, burhani dan irfani dalam terminologi kontemporer sebagai pendekatan yang bersifat multidisipliner dan interdisipliner dalam memahami Islam sebagai sebuah agama secara komprehensif. Realitas ini dpat ditemukan dalam konsep spider web Amin Abdullah bahwa dalam memahami agama Islam berlaku pendekatan "integratif-interkonektif” yang menjadikan keterhubungan antar keilmuan agama dan keilmuan umum (Musliadi, 2016). Merujuk pada deskripsi diatas, Muhammadiyah yang dikenal sebagai organisai modern dalam pengembangan pemikiran tidak akan merujuk pada pendekatan yang bersifat parsial tetapi komprehensif dan universal. Pengembangan pemikiran Muhammadiyah di era kontemporer bukan hanya memikir pada tataran konseptual an sich, tetapi merujuk pada menghadirkan Islam sebagai rabmatan lil alamin dengan perwujudan filosofinya dalam kehidupan dengan slogan baldatun taoyyibatun warabbun ghofur.

\section{KESIMPULAN}

Deskripsi dan pemaparan diatas dapat disimpulkan beberapa hal antara lain :

1. Pokok-pokok manhaj Tarjih dan Tajdid Muhammadiyah berjumlah 16 pokok uraian.

2. Kaidah manhaj tarjih Muhammadiyah meliputi : Ijma', qiyas, maslahah mursalab dan urf.
3. Metode Tarjih Muhamamdiyah meliputi 3 hal yaitu : Ijtibad bayani, ijtihad qiyasi dan ijtihad istislabi

4. Metode pengembangan pemikiran dalam Muhammadiyah meliputi : bayani, burhani dan irfani.

\section{DAFTAR PUSTAKA}

Abdurrahman, Asjmuni. 2002. Manhaj Tarjïh Muhammadiyah : Metode dan Aplikeasi. Yogyakarta : Pustaka Pelajar. Cet I.

Abbas, A. F. (2016). Integrasi Pendekatan Bayâni, Burhânî, dan 'Irfânî dalam Ijtihad Muhammadiyah. AHKAM:Jurnal Ilmu Syariah. https://doi.org/10.15408/ajis.v12i1.979

Auda, J. (2008). Maqasid Al Shari'Ah: an Introductory Guide. IIIT Publishers.

Bandarsyah, D. (2016). DINAMIKA TAJDID DALAM DAKWAH MUHAMMADIYAH. Jurnal HISTORLA.

Dennerlein, B., \& Hamid, A. (2010). Reconfiguring Islamic Tradition: Reform, Rationality, and Modernity. Religion. https://doi.org/10.1016/j.religion.2010.06.0 01

Duderija, A. (2010). Constructing the religious self and the other: Neo-traditional salafi manhaj. Islam and Christian-Muslim Relations. https://doi.org/10.1080/0959641090348187 9

Fatwa, M., Gani, E., Syariah, D. F., Ilmu, D., Uin, H., \& Riau, S. (2013). MANHAJ FATWA SYEIKH MAHMÛD SYALTFatwa, M., Gani, E., Syariah, D. F., Ilmu, D., Uin, H., \& Riau, S. (2013). MANHAJ FATWA SYEIKH MAHMÛD SYALTÛT DALAM KITAB AL FATÂWA. Hukum Islam.ÛT DALAM KITAB AL FATÂWA. Hukum Islam.

Haj, S. (2002). Reordering Islamic Orthodoxy: Muhammad ibn 'Abdul Wahhāb. The Muslim World, 92(3-4), 333-370. https://doi.org /10.1111/j.1478-1913.2002.tb03747.x

Haji Syed Hussin, S. A. (1996). Manhaj : Pengertian dan Kepentingannya Kepada 
Dakwah. Jurnal Usuluddin.

Hallaq, W. B. (1984). Was the Gate of Ijtihad Closed? International Journal of Middle East Studies. https://doi.org/10.1017/S002074380 0027598

Hasan, a. (2003). An Introduction to Collective Ijtihad (Ijtihad Jama'i): Concept and Applications. American Journal of Islamic Social Sciences.

Jalil, A. (2006). The Significances of Maslahah Concept and Doctrine of Maqasid (Objectives) Al-Shari'ah in Project Evaluation. The Journal of Muamalat and Islamic Finance Research.

Jamil, F. (1995). The Muhammadiyah and the Theory of Maqasid al-Shariah. Studia Islamika. https://doi.org/10.15408/sdi.v2i1.841

Kamali, M. H., \& Origins, T. (2008). Maqasid alShari'ah Made Simple. International Inst.of Advanced Islamic Studies,Malaysia.

Karim, A. (2015). Manhaj Imam Ahmad Ibn Hanbal Dalam Kitab Musnadnya. Riwayah.

Kim, H.-J. (2010). Praxis and Religious Authority in Islam: The Case of Ahmad Dahlan, Founder of Muhammadiyah. Studia Islamika.

Makiah, Z. (2014). Epistemologi Bayani, Burhani, dan Irfani dalam Memperoleh Pengetahuan tentang Mashlahah. Syariah. https://doi.org/http://dx.doi.org/10.18592 / syariah.v14i2.217

Musliadi, M. (2016). EPISTEMOLOGI KEILMUAN DALAM ISLAM: KAJIAN TERHADAP PEMIKIRAN M. AMIN ABDULLAH. Jurnal Ilmiah Islam Futura. https://doi.org/10.22373/jiiif.v13i2.69

Schacht, J. (1991). Muhammad Abduh. In Encyclopaedia of Islam.

Tago, M. Z. (2013). Agama dan Integrasi Sosial dalam Pemikiran Clifford Geertz. Kalam: Jurnal Studi Agama Dan Pemikiran Islam.

Zarkasyi, A. F. (2013). Tajdid dan Modernisasi Pemikiran Islam. Tsaqafah Jurnal Peradaban Islam. 